УДК 635.321:631.543.2

DOI https://doi.org/10.32848/agrar.innov.2021.8.2

\title{
УРОЖАЙНIСТЬ АРТИШОКУ (CYNARA CARDUNCULUS L. VAR. SCOLYMUS (L.) FIORI) ЗАЛЕЖНО ВІД ГУСТОТИ РОСЛИН
}

\author{
ВОЖЕГОВА Р.А. - доктор сільськогосподарських наук, професор, \\ академік Національної академії аграрних наук України \\ https://orcid.org/0000-0002-3895-5633 \\ Інститут зрошуваного землеробства Національної академії аграрних наук України \\ БІЛЯЄВА І.М. - доктор сільськогосподарських наук \\ https://orcid.org/0000-0003-0688-4209 \\ Інститут зрошуваного землеробства Національної академії аграрних наук України \\ КОкОВІХІH С.В. - доктор сільськогосподарських наук, професор \\ https://orcid.org/0000-0002-1687-6889 \\ Інститут зрошуваного землеробства Національної академії аграрних наук України \\ лиховид П.В. - кандидат сільськогосподарських наук \\ https://orcid.org/0000-0002-0314-7644 \\ Інститут зрошуваного землеробства Національної академії аграрних наук України \\ БОЙЦЕНЮК X.I. - аспірант \\ https://orcid.org/0000-0002-6572-7003 \\ Інститут зрошуваного землеробства Національної академії аграрних наук України
}

Постановка проблеми. Розвиток лікарського рослинництва є пріоритетним вектором українського аграрного сектору. Україна завдяки унікальним ґрунтово-кліматичним умовам є однією з небагатьох держав Європи, де можуть культивуватися лікарські культури різного походження з абсолютно різними вимогами до умов навколишнього середовища. На жаль, нині лікарське рослинництво в Україні не досить розвинене, ціла низка перспективних і прибуткових культур знаходиться поза увагою національного агровиробника. Однією з таких культур є артишок (Cynara cardunculus L. var. scolymus (L.) Fiori), який навіть не значиться в «Державному реєстрі сортів рослин, придатних для поширення в Україні на 2021 рік» [1]. Втім, артишок вартий пильної уваги українських аграріїв, адже культура має високу харчову й дієтично-лікувальну цінність, користується попитом на фрармацевтичному ринку. Вживання артишоку сприяє зниженню рівня холестерину, зменшує набряки, $€$ профрілактикою атеросклерозу, посилює статевий потяг, здатне зменшувати прояви гіпертонічної хвороби та інтенсивність запалення. Артишок (у їжу вживають недозрілі квітколожа кошиків) має приємний специфічний смак, є низькокалорійним продуктом (25-30 ккал на 100 г), що містить вітаміни $\mathrm{B}_{1}, \mathrm{~B}_{2}, \mathrm{~A}, \mathrm{C}$, солі калію та натрію [2].

Проте варто враховувати, що прибутковість вирощування культури прямо залежатиме від рівня конкурентоспроможності агротехнології і ринку збуту, оскільки вихід на ринок країн, де представлений артишок ПівнічноАфрриканського виробництва, не $є$ вигідним 3 економічної точки зору, оскільки рентабельність більш дорогого Європейського артишоку в такому випадку може стати катастрофрічно низькою - 3-4\% [3]. Отже, найважливішими питаннями, що потребують сучасного вирішення, $€$ інтродукція артишоку на поля України, розроблення зональної агротехніки культури задля забезпечення максимального виходу якісної продукції за мінімальних витрат матеріально-технічних і трудових ресурсів, а також виконання маркетингових досліджень щодо раціонального виходу на український і міжнародний ринки. На світовому експортному ринку зазвичай ціна на якісний артишок коливається в межах 700-1000 доларів США за 1 тону [2]. Світове виробництво лікарського делікатесу знаходиться у межах кількох млн. т на рік, основними його виробниками є Італія, Єгипет, Іспанія [2].

Аналіз останніх досліджень і публікацій. Головними проблемами, з якими стикаються аграрії під час інтродукції нових культур, є недостатня обізнаність із їх морфо-біологічними особливостями та вимогами до навколишнього середовища, що ускладнює початковий етап підбору оптимальних елементів агротехнології.

Артишок - культура родини Айстрові, походить із країн Середземноморського басейну. У стародавні часи артишок був одним із основних продуктів харчування в Єгипті. Цілеспрямоване культивування артишоку як овочевої зеленної культури у країнах Європи розпочалося відносно пізно - у XV-XVI століттях. Нині світові площі під культурою становлять приблизно 2,8-2,9 млн. га та зосереджені переважно у країнах Середземноморського басейну, США, Індії. В Україні вперше артишок з'явився у XVIII столітті, проте він не отримав поширення як харчова та лікарська культура. Донині на теренах нашої батьківщини ця рослина є екзотичною, а страви з неї по-справжньому можуть оцінити лише знавці [2].

Ніша вирощування артишоку в Україні є абсолютно вільною, не дивлячись на сприятливі агрокліматичні умови. Однією з головних проблем інтродукції артишоку $є$ абсолютна відсутність сертифікованого виробника або постачальника насіннєвого матеріалу, тому 
часто бажаючі займатися виробництвом культури натикаються на відверто низькоякісне насіння або насіння невідомого походження. Перші масштабні випробування зі сортовивчення артишоку в Україні було виконано на дослідних полях підприємства «Агро-Аналіз» (Херсонська область) із насіннєвим матеріалом, що закуповувався в невеличких пакунках у країнах Західної Європи. Технологія вирощування цієї овочевої культури зовсім не відпрацьована; на підприємстві обрали розсадний шлях із наступною висадкою в добре прогрітий відкритий ґрунт. Головними проблемами наразі $€$ відсутність гербіцидного захисту культури, а також інсектицидів і фунгіцидів для контролю попелиць і фузаріозу - основних фрітопатогенів культури в зоні сортовипробувань. Окрім того, варто налагодити процес ручного збирання врожаю, його сортування, зберігання і реалізації. Основними споживачами артишоку в Україні $€$ супермаркети та ресторани [4].

Втім зазначимо, що спроби інтродукування артишоку тривають ще з початку 2010-х років. Наприклад, на агробіостанції Житомирського державного університету (ЖДУ) було проведено міні-випробування щодо доцільності культивування культури у відкритому ґрунті. Результати пілотного дослідження показали, що умови відкритого ґрунту в зоні ЖДУ є несприятливими для вирощування артишоку, тому краще розробляти технології вирощування лікарської рослини в закритому ґрунті [5].

Уманським національним університетом садівництва було запропоновано основні засади технології вирощування артишоку. Рекомендовано такі місцеві сорти й сорти іноземного походження (жоден із них не занесений у Державний реєстр): Ранній фіолетовий, Лаонський, Майський 41, Крупний зелений, Майкопський низькорослий, Зелений глобус. Науковцями університету розроблено засади основного обробітку ґрунту, основні положення щодо удобрення та особливостей розсадного і безрозсадного вирощування культури. Цікаво, що рослину рекомендують вирощувати як багаторічник із доволі тривалим терміном використання - до 14 років [6, с. $8-12]$.

Пілотні дослідження з вивчення можливості одержання якісного врожаю артишоку на теренах України проводилися і в умовах Лівобережного Лісостепу впродовж 2006-2016 років, які засвідчили можливість одержання тут 5-25 т/га товарних кошиків та 0,8-1,2 т/га насіння культури [7].

Проте донині відсутні систематизовані результати досліджень, якими можна керуватися для надання рекомендацій агровиробникам. Вітчизняні наукові пошуки щодо вирощування артишоку є дуже обмеженими, тому нині необхідно спиратися на результати польових досліджень, виконаних за кордоном, для обґрунтування перспективних напрямів внутрішніх польових досліджень культури.

Мета дослідження - вивчення й аналіз світового досвіду вирощування артишоку за різної густоти стояння рослин культури і впливу останньої на продуктивність, а також побудова математичної поліноміальної моделі продуктивності культури залежно від її загущення.
Матеріали та методика досліджень. Нами було проаналізовано результати досліджень із вирощування артишоку за різної густоти в різних ґрунтово-кліматичних умовах і сформовано набір вихідних пар «густота урожайність» [8-14]. Математичну модель урожайності продукції будували за методом поліноміальної регресії (було обрано поліном другого ступеня як найбільш оптимальний за співвідношенням «якість підгону - реальна прогностична цінність моделі») у програмі BioStat v7 із розрахунком критеріїв точності прогнозу врожайності моделлю (величина середньої абсолютної похибки у відсотках МАРЕ) і критеріїв якості відображення моделлю реальних продукційних процесів (коефіцієнти кореляції і детермінації). Графічну апроксимацію моделі було побудовано в середовищі Microsoft Excel 365 [15].

Результати досліджень. Унаслідок узагальнення результатів наукових польових досліджень, виконаних за останні десятиліття зарубіжними науковцями, було розроблено поліноміальну регресійну модель продуктивності артишоку залежно від рівня загущення рослин. Результати статистичної оцінки моделі за критеріями MAPE, R, $R^{2}$ свідчать про достатній рівень точності та прогностичної достовірності запропонованої моделі (за $p<0,05)$ згідно Moreno et al. [16] (Табл. 1). Водночас крива апроксимації моделі забезпечує не досить високу якість підгону моделі, що можна пояснити великим розмахом амплітуди вихідних параметрів моделі. Звичайно, додавання ступенів поліному підвищує точність підгону, але тоді маємо проблему надмірного підгону моделі, коли в реальних умовах прогностична цінність її знижуватиметься під час застосування іншого (відмінного від тренувального) набору вхідних даних [17].

Таблиця 1

Статистична оцінка моделі продуктивності артишоку залежно від густоти рослин

\begin{tabular}{|l|c|}
\hline \multicolumn{1}{|c|}{ Критерій } & 3начення \\
\hline$R$ & 0.5621 \\
\hline$R^{2}$ & 0.3160 \\
\hline$R^{2}$ (коригований) & 0.2671 \\
\hline$S$ & 5.6319 \\
\hline MAРE, \% & 24.59 \\
\hline
\end{tabular}

Графічна апроксимація розробленої моделі дозволяє візуально оцінити розмах варіювання врожайності артишоку залежно від густоти рослин, а також наочно відображає основну тенденцію: найпоширенішою густотою під час вирощування культури є 10-15 тис. рослин на га (рис. 1). Дуже рідко дослідники вирощували культуру за густоти рослин понад 20 та менше 5 тис./га. Втім, параболічна крива моделі дозволяє припустити, що саме за діапазону густоти в межах 20-35 тис./га можна очікувати максимальну продуктивність артишоку, тож ми вважаємо за доцільне виконувати подальші дослідження під час інтродукування цієї культури на теренах України з урахуванням густоти вище 10 тис./га. Крім того, варто враховувати й сортові особливості артишоку, оскільки кожний генотип може мати свою реакцію на загущення. Водночас зазначимо, що в закордонних польових дослідженнях найвищу врожайність 32,90 т/га було одержано 


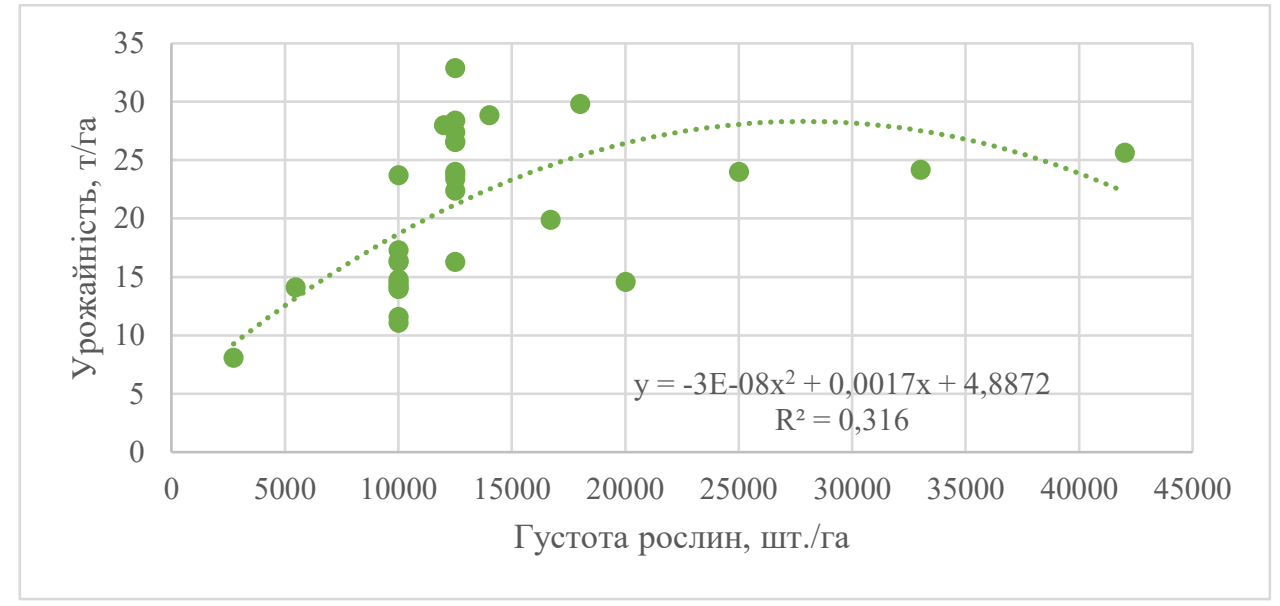

Puc. 1. Графічна апроксимація моделі продуктивності артишоку залежно від густоти рослин

за густоти рослин 12,5 тис./га, тоді як мінімальну врожайність (8,11 т/га) - за густоти 2,7 тис./га.

Висновки. Результати дослідження свідчать про те, що оптимальна густота рослин артишоку залежить від умов вирощування, проте повсюдно простежується чітка тенденція до зростання врожайності культури в умовах загущення. Математичним моделюванням установлено, що модальні величини популяції рослин артишоку на 1 га коливаються у межах 10-15 тис./га, тоді як максимально перспективною з погляду на продуктивність культури має бути величина густоти від 20 до 35 тис./га залежно від агрокліматичних умов і морфо-біологічних особливостей сорту.

\section{СПИСОК ВИКОРИСТАНОÏ ЛІТЕРАТУРИ:}

1. Державний реєстр сортів рослин, придатних для поширення в Україні на 2021 рік (станом на 06.07.2021). Київ, 2021. 524 с.

2. «Заморский цветок» - артишок. Овочі та Фрукти. 2019. № 121(12). C. 62-63.

3. Sgroi F., Fodera M., Di Trapani A.M., Tudisca S., Testa R. Profitability of artichoke growing in the Mediterranean area. HortScience. 2015. Vol. 50(9). P. 1349-1352.

4. Дышкант Д. Выращиваем артишок в Украине. Овочі та Фрукти. 2019. № 121(12). С. 59-61.

5. Кльош Ю.І., Муж Г.В. Можливості вирощування артишоку посівного (Cynara scolymus) в умовах агробіостанції ЖДУ. Біологічні дослідження - 2012: матеріали конфререниії. 2012. С. 107-110.

6. Улянич О.І., Вдовенко С.А., Ковтунюк 3.І., Кецкало В.В., Слободяник Г.Я., Воробйова Н.В., Сорока Л.В. Кравченко В.С. Біологічні особливості та вирощування малопоширених овочів: навчальний посібник. Умань : «Візаві», 2018. 278 с.

7. Хареба О.В., Горова Т.К., Позняк О.В. Біологоекологічні особливості дво- і багаторічних овочевих рослин родини Айстрові (Asteraceae Dumort). Наукові доповіді НУБіП України. 2019. № 1(77).

8. Leskovar D.I., Xu C., Agehara S. Planting configuration and plasticulture effects on growth, physiology, and yield of globe artichoke. HortScience. 2013. Vol. 48(12). P. 1496-1501.
9. Mauro R.P., Lombardo S., Longo A.M.G., Pandino G., Mauromicale G. New cropping designs of globe artichoke for industrial use. Italian Journal of Agronomy. 2011. Vol. 6(1). P. 44-49.

10. Elia A., Paolicelli F., Bianco V.V. Effect of sowing date, plant density and nitrogen fertilizer on artichoke (Cynara scolymus L.): preliminary results. Advances in Horticultural Science. 1991. Vol. 5. P. 119-122.

11. Kolodziej B., Winiarska S. The effect of selected cultivation methods on yield and quality of artichoke (Cynara scolymus L.) raw material. Acta Scientarum Polonorum. Hortorum Cultus. 2012. Vol. 11(1). P. 171-182.

12. lerna A., Mauro R.P., Mauromicale G. Biomass, grain and energy yield in Cynara cardunculus L. as affected by fertilization, genotype and harvest time. Biomass \& Bioenergy. 2011. Vol. 36. P. 404-410.

13. Ierna A., Mauro R., Mauromicale G. Improved yield and nutrient efficiency in two globe artichoke genotypes by balancing nitrogen and phosphorus supply. Agronomy for Sustainable Development. 2012. Vol. 32(3). P. 773-780.

14. Mauromicale G., Sortino O., Pesce G.R., Agnello M., Mauro R.P. Suitability of cultivated and wild cardoon as a sustainable bioenergy crop for low input cultivation in low quality Mediterranean soils. Industrial Crops and Products. 2014. Vol. 57. P. 82-89.

15. Ostertagova E. Modelling using polynomial regression. Procedia Engineering. 2012. Vol. 48. P. 500-506.

16. Moreno J.J.M., Pol A.P., Abad A.S., Blasco B.C. Using the R-MAPE index as a resistant measure of forecast accuracy. Psicothema. 2013. Vol. 25(4). P. 500-506.

17. Moksony F., Heged R. Small is beautiful. The use and interpretation of $\mathrm{R}^{2}$ in social research. Szociológiai Szemle. 1990. Special issue. P. 130-138.

\section{REFERENCES:}

1. Derzhavnyj rejestr sortiv roslyn, prydatnyh dlja poshyrennja v Ukrai'ni na 2021 rik (stanom na 06.07.2021) [State register of plant varieties suitable for dissemination in Ukraine in 2021 (dated 07/06/2021)] (2021). Kyiv [in Ukrainian].

2. Anonymous (2019). "Zamorskij tsvetok» - artishok [«Overseas flower» - artichoke]. Vegetables and Fruits, 121(12), 62-63 [in Ukrainian]. 
3. Sgroi, F., Fodera, M., Di Trapani, A. M., Tudisca, S., Testa, R. (2015). Profitability of artichoke growing in the Mediterranean area. HortScience, 50(9), 1349-1352 [in English].

4. Dyshkant, D. (2019). Vyrashchivaem artishok v Ukraine [Artichoke cultivation in Ukraine]. Vegetables and Fruits, 121(12), 59-61 [in Ukrainian].

5. Kliosh, Yu.I., Muzh, H.V. (2012). Mozhlyvosti vyroshhuvannja artyshoku posivnogo (Cynara scolymus) $v$ umovah agrobiostancii ZhDU [Possibilities of artichoke (Cynara scolymus) cultivation in the conditions of the agrobiostation At ZSU]. Biological studies - 2012: conference proceedings, 107-110 [in Ukrainian].

6. Ulianych, O.I., Vdovenko, S.A., Kovtuniuk, Z.I., Ketskalo, V.V., Slobodianyk, H.Ya., Vorobyova, N.V., Soroka, L.V., Kravchenko, V.S. (2018). Biologichni osoblyvosti i vyroshhuvannja maloposhyrenyh ovochiv: navchalnyj posibnyk [Biological features and cultivation of rare vegetables: a textbook]. Uman: «Vizavi» [in Ukrainian].

7. Khareba, O.V., Horova, T.K., Poznyak, O.V. (2019). Biologo-ekologichni osoblyvosti dvo- i bagatorichnyh ovochevyh roslyn rodyny Ajstrovi (Asteraceae Dumort) [Biological and ecological features for two- and perennial vegetable plants of the family Asteraceae (Asteraceae Dumort)]. Scientific Reports of NULES of Ukraine, 1(77) [in Ukrainian].

8. Leskovar, D.I., Xu, C., Agehara, S. (2013). Planting configuration and plasticulture effects on growth, physiology, and yield of globe artichoke. HortScience, 48(12), 1496-1501 [in English].

9. Mauro, R.P., Lombardo, S., Longo, A.M.G., Pandino, G., Mauromicale, G. (2011). New cropping designs for globe artichoke industry. Italian Journal of Agronomy, 6(1), 44-49 [in English].

10. Elia, A., Paolicelli, F., Bianco, V.V. (1991). Effect of sowing date, plant density and nitrogen fertilizer on artichoke (Cynara scolymus L.): preliminary results. Advances in Horticultural Science, 5, 119-122 [in English].

11. Kolodziej, B., Winiarska, S. (2012). The effect of selected cultivation methods on yield and quality of artichoke (Cynara scolymus L.) raw material. Acta Scientarum Polonorum. Hortorum Cultus, 11(1), 171-182 [in English].

12. lerna, A., Mauro, R.P., Mauromicale, G. (2011). Biomass, grain and energy yield in Cynara cardunculus L. as affected by fertilization, genotype and harvest time. Biomass \& Bioenergy, 36, 404-410 [in English].

13. Ierna, A., Mauro, R., Mauromicale, G. (2012). Improved yield and nutrient efficiency in two globe artichoke genotypes by balancing nitrogen and phosphorus supply. Agronomy for Sustainable Development, 32(3), 773-780 [in English].

14. Mauromicale, G., Sortino, O., Pesce, G.R., Agnello, M., Mauro, R.P. (2014). Suitability of cultivated and wild cardoon as a sustainable bioenergy crop for low input cultivation in low quality Mediterranean soils. Industrial Crops and Products, 57, 82-89 [in English].

15. Ostertagova E. (2012). Modelling using polynomial regression. Procedia Engineering, 48, 500-506 [in English].

16. Moreno, J.J.M., Pol, A.P., Abad, A.S., Blasco, B.C. (2013). Using the R-MAPE index as a resistant mea- sure of forecast accuracy. Psicothema, 25(4), 500-506 [in English].

17. Moksony, F., Heged, R. (1990). Small is beautiful. The use and interpretation of $R^{2}$ in social research. Szociológiai Szemle, Special issue, 130-138.

Вожегова Р.А., Біляєва І.М., Коквіхін С.В., Лиховид П.В., Бойценюк Х.I. Урожайність артишоку (Cynara cardunculus L. var. scolymus (L.) Fiori) залежно від густоти рослин

Мета дослідження - вивчення й аналіз світового досвіду вирощування артишоку за різної густоти рослин культури і впливу останньої на продуктивність, а також побудова математичної поліноміальної моделі продуктивності культури залежно від її загущення.

Методи дослідження: синтетико-аналітичний метод для узагальнення дослідних даних, отриманих у різних дослідженнях технології вирощування артишоку; математичний аналіз методом поліноміальної регресії (поліном другого ступеня) для побудови моделі продуктивності культури залежно від загущення ії̈ посівів; графрічна апроксимація моделі шляхом побудови графіку поліному другого ступеня та побудови параболи продуктивності культури.

Результати. Розроблена поліноміальна модель продуктивності артишоку залежно від густоти виду «Урожай $=4,8872+0,0017 \times \Gamma$ устота-3,0162× $\times 10^{-8} \times\left\lceil\right.$ устота ${ }^{2} »$ забезпечує достатню прогностичну ефективність (величина середньої абсолютної похибки моделі у відсотках MAPE - 24,59\%) та якість підгону. Аналіз результатів математичного моделювання дозволяє підкреслити необхідність вивчення агротехнології артишоку за густоти рослин від 10 до 35 тис. на га. Найменш перспективною є густота рослин артишоку в діапазонах 5-10 та понад 35 тис./га, що супроводжується зниженням продуктивності культури згідно з апроксимаційною кривою.

Висновки. Результати дослідження свідчать про те, що оптимальна густота рослин артишоку залежить від умов вирощування, проте повсюдно простежується чітка тенденція до зростання врожайності культури в умовах загущення. Математичним моделюванням установлено, що модальні величини популяції рослин артишоку на 1 га коливаються у межах 10-15 тис./га, тоді як максимально перспективними з погляду на продуктивність культури має бути величина густоти від 20 до 35 тис./га залежно від агрокліматичних умов і морфобіологічних особливостей сорту.

Ключові слова: артишок, густота рослин, математична модель, поліном, урожайність.

Vozhehova R.A., Biliaieva I.M., Kokovikhin S.V., Lykhovyd P.V., Boitseniuk K.I. Yield of artichoke (Cynara cardunculus L. var. scolymus (L.) Fiori) depending on plant density

Purpose. Study and analysis of world experience in artichoke cultivation at different plant densities and the impact of the latter on its productivity. Development of a mathematical polynomial model of the crop productivity depending on its thickening.

Methods. Synthetic-analytical method for generalization of research data obtained in various studies on artichoke cultivation technology, mathematical analysis by polynomial regression (polynomial of the second degree) to develop 
a model of the crop productivity depending on the plant density. Graphical approximation of the model by plotting a polynomial of the second degree and building a parabola of the crop productivity.

Results. The developed polynomial model of artichoke productivity depending on the plant density expressed as "Yield $=4.8872+0.0017 \times$ Density $-3.0162 \times 10^{-8} \times$ Density $^{2} "$ provides sufficient prognostic efficiency (the value of the mean absolute percentage error of the model MAPE is $24.59 \%$ ) and fit quality. Analysis of the results of mathematical modeling suggests the need to study the agrotechnology of artichoke at the densities from 10 to 35 thousand/ha. The least promising are artichoke plant densities in the ranges of 5-10 and more than 35 thousand/ ha, which are accompanied by a decrease in the crop productivity according to the approximation curve.

Conclusions. The results of the study indicate that the optimal density of artichoke plants depends on growing conditions, however, there is a clear trend to an increase in the crop yields under conditions of thickening. Mathematical modeling has shown that the modal values of the population of artichoke plants per 1 ha are within10-15 thousand/ha, while the most promising in terms of the crop productivity should be density values from 20 to 35 thousand/ha depending on agro-climatic conditions and morphobiological features of certain variety.

Key words: artichoke, plant density, mathematical model, polynomial, yield. 